\title{
Patterns of Vulnerability Among Women in Urban Flooding in Can Tho City, Vietnam
}

\author{
Ly Quoc Dang ${ }^{1}$ \\ ${ }^{1}$ Department of Women's Studies, Faculty of Social Sciences, Chiang Mai University, Chiang Mai, Thailand \\ ${ }^{2}$ Department of Socio-Economic and Policies Studies, Mekong Delta Development Research Institute, Can Tho \\ University, Can Tho City, Vietnam \\ Correspondence: Ly Quoc Dang. E-mail: lqdang@ctu.edu.vn
}

Received: November 27, 2021

Accepted: January 23, 2022

Online Published: February 28, 2022

doi:10.5539/ass.v18n3p27

URL: https://doi.org/10.5539/ass.v18n3p27

\begin{abstract}
This paper identifies the dimension of the economic impact on women, their additional roles and health problems, and limited capacity in the new flooding context. This research found that when women are exposed to different levels of flooding, they have different susceptibilities. Women in low flooding level are less susceptible and vice versa. The susceptibilities are the economic losses, the external roles and health problems. From the consequences of those susceptibilities, it created the burden on women, which created less opportunities to participate in learning and improving new knowledge compared to men in their families and communities. The research found that women are always more vulnerable than men in flooding disasters. It also meant that women are "victim" subjects. Women faced the problem because of the social norms, it has not been changing in the gender differences. Therefore, society needs to change the way to look at women, not seeing them as "victim" objects. This research used secondary data to review the existing information on socio-economic contexts in order to obtain the overall picture of the field site and the women's life changes, semi-structured interviews, participant observation, and key information personals.
\end{abstract}

Keywords: women, urban flooding, patterns of vulnerability, Can Tho, Vietnam

\section{Introduction}

The cities throughout Asia are growing rapidly and are of increasing importance to these countries' development trajectories. These cities are highly vulnerable, however, to the risks posed by climate change, particularly floods, because of their geographic location, limited governance capacity, and uncurbed urbanisation. Vietnamese cities, in particular, are vulnerable to the threat of climate change. The country was ranked $7^{\text {th }}$ in the 2016 Global Climate Risk Index. Can Tho City is located in the centre of the Mekong Delta, Southern Part of Vietnam. The city is right next to Hau River, a branch of Mekong River in Vietnam. Can Tho City recognises and considers as the largest city in the Mekong Delta, which was a primary city in 2004. In the past, the flooding areas were generally divided into two main areas, an upper city which dealt with the natural flooding and a lower city (urban site of the city) which dealt with the inundation flooding. Recently, the flooding has changed, especially in urban areas. The flooding area was determined around 30 percent of total area in the past; that number has recently increased up to 50 percent (Huong \& Pathirana, 2013). Some urban areas have risen by $35 \mathrm{~cm}$ to $50 \mathrm{~cm}$ respectively (Huong \& Pathirana, 2013; Danh, 2014), or even $80 \mathrm{~cm}$ (Danh, 2014).

This research found that the "new urban flooding" is mainly created by climate change and urbanisation. Can Tho City is located next to the river, the coastal area in the Mekong Delta. This city experiences the flooding issue which was created by inundation and natural flooding. From 2004 to 2019, this city has developed significantly, it is the most urbanised in the region. The rate of urbanisation was $49.84 \%$ (2004), moved to $51.92 \%$ (2008) (CPC, 2017), this city is presented to be central for education, commercial, and medical services in the Mekong Delta (Trung, 2014). Huong \& Pathirana (2013) demonstrated that urbanisation created flooding, many infrastructures and planning have done, which could not manage the water well (Ehlert, 2011). In climate change factor, the rainfall in city has changed and increased. This city is a location projected to increase the highest on the impact of climate change in Vietnam, and one of the most climate change vulnerable regions of the world (MONRE, 2012). The average number of days of rainfall and the amount of rainfall has increased since 1978 (Phung, 2012), this author also demonstrated that the rainfall in the city is around $82-87 \%$ which increased the 
various years, 2005-2010, and the rainfall increased 5\% during the period of 1980-1990.

The flooding in Can Tho City has occurred differently compared to the past, which was caused by urbanisation and climate change. In other words, the flooding has changed in a natural way to another way which is interacted by human action, it so-calls "new flooding" in urban sites in the city. This new environmental phenomenon created more challenges and difficulties for the local people. When flooding occurs in their families, each of them is vulnerable differently. Women are estimated to be more concerned, then it creates more harm and damages to them. While Garschagen (2015) has conducted extensive research on the governance of flooding in Can Tho, there exists a gap in his research. He has hardly touched on the gender dimensions of flooding vulnerability and governance at the community and household level. In addition, Danh (2015) \& Chinh et al. (2016) showed the economic losses among families and society in urban flooding in Can Tho City. However, the women's dimension has missed focus. Using the patterns of vulnerability, this paper therefore seeks to address this gap.

The paper identifies the different economic impact among women, and the differing roles and responsibilities among women in the different communities in Can Tho City. This paper takes into the dimension of the economic impact on women, their additional roles and health problems, and limited capacity in the new flooding context. This used to analyze and present the vulnerability differently between women and men, and among women. This framework was proposed by Birkmann (2013), and it is based on three patterns: exposure, susceptivity, and lack of capacity. Women and men as well as among women are vulnerable differently because each of them has different susceptivity and capacities in the flooding conditions. In this sense, women lost incomes and costs from flooding, women spent more time dealing with the floods, and their health got worse. Due to those problems, this paper identified that the capacities of women are limited, that's why they got worse. The loss of incomes and costs are including their costs on personal consumption (e.g. medicines, skincare, equipment, etc), their own business losses and unemployment (e.g. personal livelihood activities, part-time work, etc), and household assets' loss (e.g. wall and floor collapses, houses' upgrading and improvement, etc). The additional roles are their earning roles in the flooding period. When they have overloaded work, they become more tired. The limited capacities are about women's new knowledge about flooding, women's economic condition, and the necessary information about local planning through local participation.

This paper is designed to target the affected women in the flooding condition in order to identify and understand their three different losses, their additional roles and responsibility which impact on their health, and their limited capacities. This paper supposed that women are vulnerable in the new flooding situation based on those dimensions. Understanding the different vulnerability among women, and to men in the flooding condition, is very important in order to see that everyone is different. It helps to imply the suitable policies and appropriate policies and development programmes effectively.

Some papers and policy works from the government still do not discuss the relation between women and flooding, it also does not discuss much the differences between women and men. This paper would contribute to this problem, then different development programmes would be referred, and relevant policies would be proposed and enforced. For example, the 2017 Law on Gender Equality in Vietnam discussed gender equality on different social and political issues, but the specific urban flooding has not touched yet. In addition, this paper would contribute the dimension of gender differences into the development planning in Vietnam, which has planned to propose and implement, even the international and national climate change adaptation strategies.

From a Feminist perspective, vulnerability is understood to be comprised of both negative and positive experiences: the negative experiences exposes the harm and stress, and the positive experience exposes to the care and love (Lubrano, 2013). In environmental perspective, vulnerability is understood as risk and shock on one side, and the defencelessness to cope with (Chambers, 2006). To support the above knowledge, Birkmann (2013) provided the Methods for Improvement of Vulnerability Assessment (MOVE) framework of natural hazards in order to frame vulnerability risk and society in order to identify the original vulnerability in any environmental hazard in our society. Three patterns of exposure, susceptibility, and limited capacity, are in the framework in order to identify the different vulnerability among women, and to men.

What is more study about vulnerability, Maitainbanadzo (2013) stated that vulnerability is a universal constant for a human-being. The vulnerability is a universal pursuit of its scholarly interventions by starting from the recognising that human beings are inherently characterised by a universal and constant vulnerability that arise from human bodies and embodied pain, pleasure, and need. Different women have different social groups and have different vulnerability, elders are more vulnerable than the younger (Mustafa, 2015), urban poor are more vulnerable than upper-class (Bohle, Downing, \& Watts, 1994). In term of livelihood backgrounds, large business 
are more in loss (Danh, 2015; Chinh et al., 2016)

In related studies, the differential vulnerability is understood and analysed between patterns of susceptivity and limited capacity in the different flooding exposures. In the pattern of susceptivity, women are studied on their economic losses. Few \& Tran (2010) found that women in the Mekong Delta increased anxiety, fear and intra-household tensions as the result of dangers and damages associated with flooding and its livelihood impacts. In other studies in Pakistan, Ajibade \& Rachel (2013) reflected that women are worried about their own business at home during the flooding period because it damages their business activity. During the flooding period, women earned more home's roles which are the external roles; childcare and relative-care, and home's business. When women are at home, they normally added their home's roles to deal with the floods (Enarson, 2011; Ajibade \& Rachel, 2013), women also earned their childcare and relative cares (Enarson, 2011; Ajibade \& Rachel, 2013; Dahlerg, Albris, \& Jebens, 2017), and women earned their additional roles because of their home businesses (Ajibade \& Rachel, 2013). While doing more roles under the water, women are supposed to be more likely to fall sick and have body problems (Mustafa, 2005), stress and worry (Chanthy \& Samchan, 2014). In the pattern of limited capacity, women are found to limit on access to basic facility like health, education and safely from periodic flooding (Mustafa, 2005), lacked planning policy, training, and political arrangement (Mustafa, 2005; Ajibade \& Rachel, 2013; Anh et al., 2016).

In order to approach the different vulnerability among women, this paper considers three patterns of vulnerability to identify and understand how they are in differential flooding levels, their economic impacts, their additional roles, bodily impact, and limited capacities. When women are identified, their level of vulnerability is measured and determined.

\section{Method}

\subsection{Research Site}

This research is conducted in Can Tho City in order to discuss different vulnerabilities in the flooding situation for women. This research chose the potential respondents who are the affected women in the flooding situation, it preferred to diverse locations and social groups.

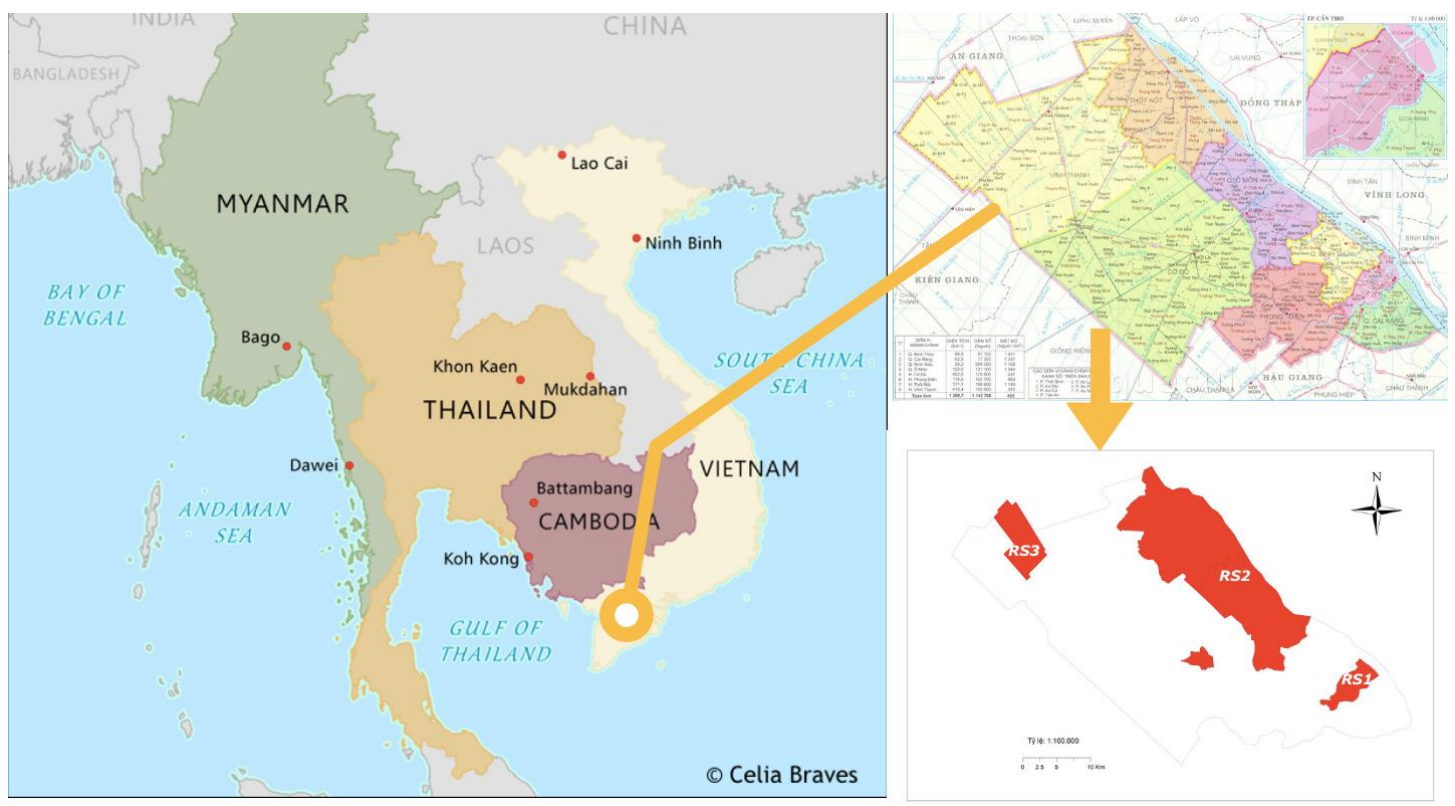

Map 1.2 The Research Sites in Cần Thơ City (Source: author, 2021)

Women in the research sites are from different jobs, livelihood backgrounds, and other social differences, including labor, seller shop owners, mobility sellers, riders and drivers, teachers, officers, unemployed, tailors, workers, and so on, through different classes, ethnicity, religious, women and party members, marriage statuses, geographical location, size of families, and so on. They cannot predict and adapt well due to the number of water sources and little information about urban development planning, especially women who are marginalised groups to the others. 


\subsection{Research Time}

This research observed the flooding period and observed the affected women, men in the research field from September 10th, 2019 to October 9th, 2019. During These 30-days, 32 flooding events (32 days, twice a day) occurred as the inundation period. Local people were exposed to the flooding level because of the rains which occurred very seriously during this time too.

\subsection{Research Data Collection}

The process of data collection of this research used a method of ethnography. Ellis (2004) remarked that ethnography includes everyone gathering information: survey, hanging around, making conservation, asking the question, life story, formal interviews, and information data collection. Therefore, this research will start with the secondary data collection, household survey, then follows with an in depth-interviews, participant observation, and mapping.

This research used secondary data to review the existing information on socio-economic contexts in order to obtain the overall picture of the field site and the women's life changes. The Ethnographic household survey provided rich information on the basic life situation, such as social and economic, and environmental issues in each family, as well as family members to see different marriage statuses; ages; education level; gender; ethnicity, religion; citizenship status; land, house ownership, and type of house, income and expenditure, occupation and type of employment. After that, the survey provided information about respondents' living conditions by observing and discussing their houses, including the number of rooms, household material and household properties, all of those can be understood how the level of wealth is different in each family (which is difficult to identify class differences among them). A household survey was designed by the researcher in Vietnamese, and it was fulfilled by 24 women ( 24 families) in the research site as the structure interviews who are affected by flooding in three different research areas. The researcher communicated with interviewees in the local Vietnamese dialect or Khmer dialect if the respondents are of Khmer Ethnicity (I can communicate this language because I am a Khmer Ethnicity Group too). The researcher chose the interviewees based on research requirements, such as women who are affected by flooding from different social-economic, educational backgrounds, ages, religions, and so on in order to provide a diverse and complex research sample. This research targeted the 21 families as 21 women in the family in various classes: lower, middle, and upper incomes.

\subsection{Research Unit and Level of Analysis}

The unit of analysis of this research was women's practices in daily and to dealing with flooding situations that are based on the family, kinship level, community, and working place levels by operationalisation, it focused on Can Tho women's life trajectories on gender relations, empowerment, and differences.

\subsection{Research Data Analysis}

The data analysis was based on the methods mentioned earlier to give an in-depth analysis of women's everyday lives and flooding. It was done and analysed during fieldwork and after the data collection in order to study the women's life experiences. Women are vulnerable differently from the floods. Based on the research question, this research firstly analysed that how women expose to floods differently, how they are sensitive to the flooding situation, how they damaged the loss, and how they lacked the capacity to adapt to the floods. I also analysed some data on how women are more vulnerable due to their roles at domestic and community levels or roles of production and reproduction at their families and working places.

\section{Results}

Table 3.1 Women's Participants and Their Different Social, Economic, \& Environmental Backgrounds (Source: author, 2021)

\begin{tabular}{|c|c|c|c|c|c|c|c|c|c|c|c|c|}
\hline $\mathrm{N}$ & $\mathrm{Na}$ & MS & YoB & Eth. & $\begin{array}{l}\text { Livelihood } \\
\text { Backgrounds }\end{array}$ & $\begin{array}{c}\text { In. } \\
\text { (USD) }\end{array}$ & C. & $\begin{array}{c}\text { P.L } \\
\text { (USD) }\end{array}$ & $\begin{array}{l}\text { P.L.L } \\
\text { (USD) }\end{array}$ & $\begin{array}{c}\text { H.L } \\
\text { (USD) }\end{array}$ & $\begin{array}{l}\text { F.L } \\
(\mathrm{cm})\end{array}$ & H.Ls \\
\hline 1 & L.H & $\mathrm{M}$ & 1970 & Kinh & $\begin{array}{l}\text { Lecturer + } \\
\text { English } \\
\text { Education }\end{array}$ & 800 & $\mathrm{U}$ & 55 & 912 & 600 & $10-30$ & Inner \\
\hline 2 & N.M & W & 1964 & Kinh & $\begin{array}{c}\text { Small Shop at } \\
\text { Home }\end{array}$ & 90 & $\mathrm{~L}$ & 20 & 170 & 450 & $10-30$ & Inner \\
\hline 3 & P.H & W & 1959 & Kinh & $\begin{array}{c}\text { Small Shop at } \\
\text { Home }\end{array}$ & 400 & M & 14 & 400 & 237 & $10-30$ & Inner \\
\hline
\end{tabular}




\begin{tabular}{|c|c|c|c|c|c|c|c|c|c|c|c|c|}
\hline 4 & N.O & M & 1968 & Kinh & $\begin{array}{l}\text { Small Grocery } \\
\text { Store at Home }\end{array}$ & 110 & $\mathrm{~L}$ & 20 & 60 & 170 & $10-30$ & Inner \\
\hline 5 & D.N & W & 1948 & Kinh & Street Seller & 107 & M & 25 & 45 & 367 & $10-30$ & Inner \\
\hline 6 & N.C & M & 1957 & Kinh & $\begin{array}{l}\text { Small Grocery } \\
\text { Store at Home }\end{array}$ & 130 & $\mathrm{~L}$ & 21 & 50 & 237 & $10-30$ & Inner \\
\hline 7 & V.L & $\mathrm{W}$ & 1956 & Kinh & $\begin{array}{c}\text { Retired }+ \\
\text { Housing for Rent }\end{array}$ & 302 & M & 22 & 90 & 1295 & $10-30$ & Inner \\
\hline 8 & P.H & M & 1959 & Kinh & Street Seller & 110 & $\mathrm{~L}$ & 25 & 60 & 82 & $10-30$ & River \\
\hline 9 & V.N & $\mathrm{W}$ & 1941 & Kinh & $\begin{array}{c}\text { Elder + } \\
\text { Houseworker }\end{array}$ & 55 & $\mathrm{~L}$ & 20 & 0 & 270 & $30-50$ & River \\
\hline 10 & P.A & M & 1952 & Kinh & Lottery Seller & 130 & $\mathrm{~L}$ & 13 & 30 & 80 & $30-50$ & River \\
\hline 11 & P.N & M & 1956 & Kinh & $\begin{array}{c}\text { Small Shop at } \\
\text { Home }\end{array}$ & 102 & $\mathrm{~L}$ & 20 & 70 & 160 & $30-50$ & River \\
\hline 12 & T.L & M & 1963 & Kinh & Tailer + Shipper & 107 & $\mathrm{~L}$ & 32 & 140 & 180 & $30-50$ & River \\
\hline 13 & L.L & M & 1970 & Kinh & $\begin{array}{l}\text { Small Grocery } \\
\text { Store at Home }\end{array}$ & 75 & $\mathrm{~L}$ & 25 & 155 & 4500 & $10-30$ & River \\
\hline 14 & P.T & M & 1980 & Kinh & Part-Time Job & 110 & $\mathrm{~L}$ & 53 & 0 & 234 & $10-30$ & River \\
\hline 15 & T.H & $\mathrm{W}$ & 1968 & Khmer & Houseworker & 85 & $\mathrm{~L}$ & 20 & 0 & 120 & $10-30$ & Canal \\
\hline 16 & L.Th & M & 1985 & Kinh & Street Seller & 190 & M & 20 & 100 & 20 & 10 & Inner \\
\hline 17 & L.Tha & M & 1980 & Kinh & $\begin{array}{l}\text { Small Grocery } \\
\text { Store at Home }\end{array}$ & 95 & M & 15 & 50 & 730 & $10-30$ & Canal \\
\hline 18 & D.L & M & 1968 & Khmer & $\begin{array}{l}\text { Small Shop at } \\
\text { Home }\end{array}$ & 85 & $\mathrm{~L}$ & 12 & 23 & 75 & $10-30$ & Canal \\
\hline 19 & M.T & M & 1976 & Khmer & Bottle Collector & 73 & $\mathrm{~L}$ & 15 & 0 & 60 & $10-30$ & Canal \\
\hline 20 & T.C & M & 1978 & Khmer & Part-Time Job & 120 & $\mathrm{~L}$ & 45 & 0 & 80 & $10-30$ & Canal \\
\hline 21 & L.M & M & 1962 & Kinh & Market Seller & 540 & $\mathrm{U}$ & 47 & 180 & 302 & $10-30$ & Inner \\
\hline
\end{tabular}

Notes: N- number; Na- Name; MS- Married Status; YoB- Year of Birthday; Eth.- Ethnicity; In. - Income; C.- Class; L- Lower Income; M- Middle-Income; U- Upper Income; P.L- Personal Loss; P.L.L- Personal Livelihood Loss; H.L- Household Loss; F.L- Flooding Levels; H.Ls - House Locations

\subsection{Flooding Exposures}

According to Table 3.1 above, the 21 women's participants in the research in three communities in the city faced different levels of flooding. Three levels of flooding that the article recorded: (i) flooding level is about $10 \mathrm{~cm}$; (ii) the flooding level is about $10-30 \mathrm{~cm}$; and (iii) the flooding level is about $30-50 \mathrm{~cm}$. In the 21 women's participants, 1 woman faced the flooding level of about $10 \mathrm{~cm}$, the 16 women faced the flooding level of about $10-30 \mathrm{~cm}$, and the 4 women faced the flooding level of $30-50 \mathrm{~cm}$. Women faced deeper and more severe flooding, located in riverside and canal areas because of the rapid and easy rising of water from these sources.

This research learned from one of cases, Mrs. P.A (An Binh Community) about how she exposed the flooding level at her home, she said:

"Oh my gosh, the water is too much and I did not know where it was coming from! It is not like that last time. As you saw, it flowed very fast from the river to my home. In the last time, the floods still occurred, but it was not so fast nor released so fast. Now, it is so weird, the water is too much and it is slowly withdrawing. The water level is $30-50 \mathrm{~cm}$ different between the last and current time, as you can see on my house's wall. My house actually dealt with the floods last time, but it was smaller. It did not rise to that level last time, but it has come to that level recently."

In another case of the 21 women's participants, this research learned from Ms. L.H (An Hoa Community) about how she exposed the flooding level at her home and living site, she said:

"The recent floods occurred at our home while the last one did not. Last time, the flood waters rose from small canals, but these canals are filled up to create streets, alleys, houses and buildings. Recently, the floods occurred after raining. The water flew from the river and canal too. If the rain was heavy and long, the floods occurred seriously, and vice versa. The flooding level between the last 15 years and the current 
time is about 10 to $30 \mathrm{~cm}$. In the period of flooding, the flood waters released very fast; it was very slow this time."

However, some women faced less flooding even though they were located near rivers and canals. Specifically, the 8 women faced the flooding level of about $10-30 \mathrm{~cm}$, these women located along rivers and canals. The article found that the reason for these women was in less flooding level because their house height is quite high. Most of those houses are quite new, which were built less than 10 years ago. The 8 women located inside (far from rivers and canals), faced the flooding level of about $10-30 \mathrm{~cm}$, and the 1 woman faced the flooding level of about $10 \mathrm{~cm}$. The reason was that their locations are little far from rivers and canals, the flow of water was slow, low, and less from those sources. Moreover, this location was blocked by the other infrastructures in the community, so those women are also less prone to flooding. And, the flooding in the inner location was released slowly.

\subsection{Susceptivity}

The research found that the women participants faced economic loss, they had to work more and that made them more ham to their health in the context of flooding. This is considered to be a sensitive issue which they faced.

\subsubsection{Economic Losses}

According to Table 3.1 above, the article found that 21 women's participants experienced economic loss, and there is a difference between them. There are three losses that the article would like to share: the loss based on personal spending to protect and restore their personal health (personal loss), loss based on individual's livelihood status (personal livelihood loss), and the loss based on the impact on the household assets (household asset loss).

\section{(a) Personal Economic Loss}

According to Table 3.1 above, the total personal loss on the 21 women's participants was 539 USD, an average of about 26 USD each. The lowest loss was Ms. D.L, she spent about 12 USD, and the highest was Ms. L.H, this woman spent about 55 USD. The article recorded that this loss was used in the cost of medicines, lotions, oils (dầu gió, dầu cù là), health care items, fixing of motorbikes and bicycles fee, etc. Ms. D.L lost less because she spent little on these expenses, she only bought lotions and oils. Meanwhile, Ms. L.H lost high, this woman not only used the money for medicines, skincare, but also for the protective equipments such as rubber shoes; gloves in order to protect her body in the flooding condition at her home, Ms. L.H (An Hoa Community) said:

"It is so dangerous! You could see that my feet and hands are getting red, scabies, I feel itchy a lot [she was saying that and pointing to her body]"

Among 21 women's participants, another case, Ms. M.T (Chau Van Liem Community) also said that:

"My body got itchy, red, and scabies because I was in the water too long"

In the above two typical cases, both Ms. L.H and Ms. M.T got skin problems such as scabies, itching, redness, etc. The article recorded that these are signs that all women did. Women have these problems on their bodies because they are exposed to water for a long time and many times. They worked in the house, or even went out to earn money during the flooding. In fact, this water source was not clean because it was mixed with other water sources from canals, sewers, etc., containing a lot of toxins and bacteria.

\section{(b) Personal Livelihood Loss}

According to Table 3.1 above, the total personal livelihood loss on the 21 women's participants was 2,535 USD, an average of about 121 USD each. The lowest loss was zero USD, and the highest was about 912 USD. Women recorded to run and own different kinds of job activities: lecturer (1), small shop at home (4), small grocery store at home (4), street seller (3), house for rent (1), house-worker (2), lottery seller (1), tailer and shipper (1), part-time job (2), bottle collector (1), and market seller (1).

The 5 women are in the zero loss, this article recorded that the 2 women did not involve in the livelihood activity as they are the house-workers (nội trợ), the other 2 women are involving in the part-time jobs, and the 1 woman was the bottle collector. The part-time job women managed their times well in order that their income did not influence, Ms. P.T (An Binh Community) told:

"In the flooding days, I contacted my workplace to be late. If I was one hour late, I worked overtime for an hour that day, so my salary is not deducted."

In another case, Ms. M.T (Chau Van Liem Community) recorded not to be influenced her income even though she involved in it in the flooding period, she said: 
"I still collected the bottles in the flooding period. It did not influence my income. The bottles are easy to collect during floods because they are light and float on the water, so I could see them easily"

In contrast, the large loss was 912 USD, this loss was in Ms. L.H's business. Ms. L.H was a lecturer in the university. Actually, her monthly income from university was not influenced in the flooding period even though she postponed the classes in the flooding period. But, this loss was into her own business, the English Education Centre that she did not get much the learners in the flooding period, she said:

"In the flooding period, my business was damaged very much! Many students could not register for the English courses, and many students could not go to the classes."

Through the above cases, it can be seen that few women did not lose any in the flooding period, these jobs are considered independent of others, and they could arrange their times, negotiate well in their working places. In the opposite case, women's business activities are also greatly lost because most of their customers are not proactive during the flooding.

In short, women lost some costs during the flooding because they could not handle business well, sell, do shipping, transport goods, etc. However, there are still a few women who did not lose by the specificity of their works. In the gender difference about this loss, this article did not record this loss much on men in their families because men normally went to the offices, the working places. Men's jobs recorded stable, high and major incomes in the families.

\section{(c) Household Asset Loss}

According to Table 3.1 above, the total household asset loss on the 21 women's participants was 10,249 USD, an average of about 488 USD each. The lowest loss was 20 USD, and the highest was about 4,500 USD.

This loss represented the expenses on the housing, including: breakage and damage to the floors, walls; household appliances and equipment, costs of purchasing construction materials and equipment, sandbags, pumps, trailers, rubber shields, labor costs, transportation costs, costs of building a new home or upgrading, repairing, etc.

The reason why the cost is quite high in Ms. L.L's family (An Binh Community), 4,500 USD, she and her other family members used this money to rebuild the house. Therefore, the cost was much higher than the other families. The article found that no other cases could be found in this study. In the opposite case, Ms. L.Th (An Binh Community) and the other family members only spent about 20 USD because they rented this boarding house (nhà trọ), which was owned by someone else. The loss was borne by the owner. Ms. L.Th and her family members only spent this small amount to buy some construction materials such as cement, sand, bricks for the temporary wall.

In short, women as well as other family members lost the high cost for their household assets, and the cost greatly influenced the total cost of their families. However, the woman staying at the boarding house was less lost because this house was not owned by her.

\subsubsection{The External Roles and Health Impacts}

The article found that all women's participants spent the external roles or additional roles in order to deal with the flooding in their homes besides of their actual work in the normal situation, income activity. When women worked more, their health problems became more serious because of overloading, they did not have time to rest. The two case below are representative of this issue:

\section{Case 1: Elder Woman, Mrs. V.N (An Binh Community)}

I called Mrs. V.N "old woman" because her age is identified in the elder group, 78 years old. Being elder, it is extremely difficult for her to move around the house and the issue is serious to herself, so I asked her:

"How did the flood waters $r$ create difficulties to you, Mrs.?"

"I felt uncomfortable moving around my living site, e.g., front yard, inside of home, etc...", she said.

"How hard?", I asked

"It is extremely hard, son"! As you can see, there is too much flood water at home (she was talking and pointing at me around my fingers. She took a seat this time while having a talk with me). I feel pain and hurt my back a lot because I must spend a lot of time dealing with the flood water at home. Being older, it

\footnotetext{
${ }^{1}$ Mostly, elders call younger people "con" as their son's or daughter's ages.
} 
is hard to sleep, and ii is harder to sleep when the flood water occurs," she responded.

I could imagine how hard it was for her to move around the house during the period of flooding because I have also experienced that difficulty. During the visit, I sometimes observed that she worked and dealt with the water at her home alone. She walked around the house and arranged things, pushed the water out of the house, and cleaned and swept the home's floors. No one in the family could help her to do the home chore-work, Mrs. V.N was a main family member, she was the only one who does such work. I was also told by her that she has fallen down on the floor twice in the period of flooding because the floor is slippery. This is because the floor was embedded by mud and sedimentation from the river, and it created a very slippery condition. She could not manage to watch that. In addition, her body was getting itchy, red, and even scabies because she was under the floodwater for so long. As a result, she had to spend some money to take care of her body due to that problem. Regarding to her sleep issue, I was curious as to why it was hard for her to sleep, so I asked:

"Why is sleeping so hard for you, Mrs.?".

"The flood waters rose up to my bed, so I could not sleep! I was worried about all the things (the facilities/devices/equipment/properties) at home. Therefore, I could not sleep during that period," she expressed.

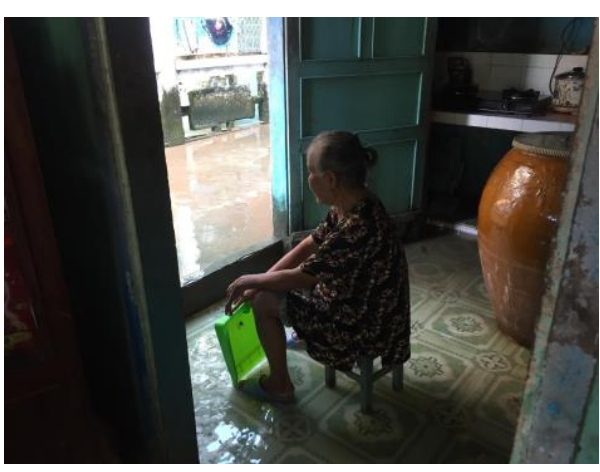

Photo 3.1 Mrs. V.N was working to solve flooding situation (Source: author, 2019)

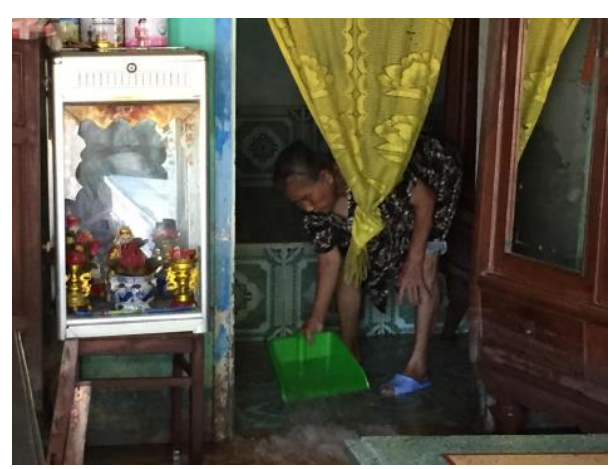

Photo 3.2 Mrs. V.N was working to solve flooding situation (Source: author, 2019)

The photos above showed that she was trying to solve flooding situations in different parts of the house. Mrs. N is a widow; she lives with her daughter and grandchild. Her daughter was mostly working at the factory nearby, and she did not involve herself much in family roles. Therefore, Mrs. V.N is the main family member who is responsible for the home's roles. She not only does the home's roles, but also solves the flooding problem occurring at her house. Her daughters, sons, and grandchild rarely visited her in order to bring her to the hospital, take care of her, and even help her to solve the floods. The photos show that she felt tired, harmed, and pain in her body too much while working in this condition.

\section{Case 2: Disable Woman, Ms. L.Tha (An Binh Community)}

Ms. Tha runs a small grocery store at home. In the flooding situation, Ms. Tha was busy with her actual work such as cooking, taking care of children, and selling things at the store. She had to take care of those things in order to avoid flood damages, to deal with the floodwater to protect her home, and to watch carefully for her children. I tried to investigate deeply about her disadvantages in the flooding situation, so I asked:

"Is the flooding situation difficult for you, Ms.?"

"Very inconvenient, brother! You see that it is already inconvenient in a normal situation as my disability status," she said.

"How inconvenient?", I asked.

"My husband normally worked outside of the home, and I have a little kid. I am afraid of my kid falling because the floor is slippery. I asked her to sit down in one place and I watched her. The flooding covered all the homes, which was polluted and dirty each time", she said.

I could understand her situation because I was at her home during the flooding time. She has to walk through the water in the flooding time for hours. Each time a customer stops by, she has to go through the flood water to take something for that client. I am curious whether someone helps her in this flooding situation, I asked: 
"Has someone helped you, Ms.?"

"No!", she said.

"How did you deal with the flood waters then?", I asked.

"I try to move up those selling my stuff in order to avoid the damages. I am just under it till the flood waters are dredged clearly. Then, I cleaned and swept the floor, and sometimes I pushed the water out. I just spent more time on it.", she said.

Both women carried out more roles in the flooding situation and took more time to deal with it instead of resting and doing something else. Mrs. V.N was old, she took more roles to arrange the home's stuff, slapped the water out, cleaned and swept the home's floor in every flooding time. She was actually not very well due to her age, this external work created more problems for her. She was recorded to be in pain and weak because she did too much work. Ms. L.Tha was recorded to earn the external roles as Mrs. V.N. Moreover, she earned other roles by taking care of her kid, and her grocery business at home. Ms. L.Th was already an inconvenience to herself because of her physical condition. It is more inconvenient for her to move around the home in the flooding situation because of her disability status.

In short, women earned more roles in the flooding period, this created double and/or even triple works on them. Women not only involved in their home's roles, took care of children, but also for their economic purposes in the society. Depending on women's social characteristics, each woman earned different amounts of roles, then they problematised differently on their personal health. The article found that women are actually associated with roles in the family. This division of labor phenomenon has existed in society for a long time because it is influenced by social norms as well as the stereotypes. This caused women to take more roles than men in the family, although there was also the change in gender roles in dealing with the flooding. However, women are still under the norms.

\subsection{Limited Capacities}

The article found that the limitation of women's capacities to adapt, respond to and recover from flooding created the vulnerability on women. The capacity of women that the article recorded included new knowledge of new flooding, practical experience, financial capacity, and limited support from the other family members.

According to Table 3.1 above, the 14 women are still in the lower-income group and the 5 women are in the middle-income group. Based on their livelihood backgrounds and recent incomes, those are not stable and high, the lowest was around 55 USD, and many women earned not much.

They, of course, limited the financial capital in order to cope with the new flooding. It meant women did not have money to upgrade and rebuild their houses, one of women's participant, Mrs. P.A (An Binh Community) said:

"It is so distressful (khổ)! I do not expect to upgrade or build a new one, just live like this year by year; maybe we would sell this house and buy a new one in another community"

In another limited capacity, most of women did not attend the meeting and social activities in the local community because of their working condition, Ms. L.Th (An Binh Community) said:

"My husband attended the local meeting and other social activities. I did not do it because I was busy with my business, taking care of home's roles, and my body condition".

The above two typical cases showed that, Mrs. P.A. was low in her economic condition, the house was not rebuilt, renovated to escape from flooding. She wanted to sell this house and land, and to go elsewhere. In the second case, Ms. L.Tha ran her business at home, she also spent time on her chore works, she could not attend the meeting. In addition, Ms. L.Tha recorded that she could not walk easily due to her physical condition, so she did not participate in any meeting and other social activities. Missing to participate in the meeting meant that they could lack some necessary information, such as, local planning, knowledge through sharing from others. In the result, it was the reason why women limited their new knowledge through this missing participation.

\section{Discussion}

The result showed that women exposed the flooding levels differently. When exposed to the water, the bodies of women are sensitive, the sensitivities are the economic losses, and the losses are divided into three different losses to distinguish among women. Women lost their incomes, household assets, and personal expenses during the flooding period, which they did not face in the normal situation. This loss created their lives more difficult, especially in the low-income group. There was a difference among women in this loss, women in the 
upper-income group, in large business models, and livelihoods, have higher losses, and vice versa. In gender differences, the result showed that there are differences between women and men in the loss. Men's jobs are less influential because those jobs are the main livelihood activity, high-income, and stable in the families. Therefore, the men's jobs still worked, while women's jobs were postponed, and stopped. While women have no income, they lose the other expenses. They are more dependent on men, then their voices in the family are also less. In other words, the gender relation has changed, and women's power and voices in the family are getting less.

In the second sensitivity, women are divided to spend the extra time during the flooding period, which leads to more serious health problems. They are overloaded with work, and they are touching too much and too long the water which is supposed to be polluted. Among women there are differences, women in the upper-income group are less harmed than the other lower-income group, the younger women are less harmed than the elderly group, the disabled women are larger than the other women. Moreover, some women were still involved in the income activity in the flooding period, this created even more harm to them due to the fact that they have much work to do for their families. In gender differences, the result showed that women are divided to deal with the flooding in the family because of their roles and their jobs. Men in the family rarely participated because they mainly spent their time working outside in the income activity. With these different roles, women are harmed in the flooding period as they spend more time and work.

During the flooding period, women were limited in their capacities, these capacities are the new knowledge, the new experience in the flooding management, and the financial capacity. Due to the influence of sensitivity, women reached these limitations. In normal circumstances, women already spent a lot of time on domestic work, children, and even economies, which has created limited conditions to participate in local activities and meetings. In the flooding period, the result found that women are busier as they have to do more household chores, deal with the water, take care of their children and relatives, and even involve themselves in the livelihood activities. This extra work limited themselves in participating in the local events and activities, then they limited the new knowledge and experiences. In addition, due to financial constraints, e.g. unstable and low incomes, women have less power on decision-making in building and renovating their houses in order to escape the flooding.

In the three patterns of vulnerability, the result showed that when women are exposed to different levels of flooding, they have different susceptibilities. Women in low flooding level are less susceptible and vice versa. However, depending on other social characteristics, the susceptibilities are different even though there was a difference in the levels of the flooding. From the consequences of those susceptibilities, it created the other works on women, which created less opportunities to participate in learning and improving new knowledge compared to men in their families and communities. The research found that the influence of the gender social norms, the stereotypes are the consequences of the problems on women. The flooding created greater inadequacies, and the larger gap. Based on these three patterns, the research showed that, among women are different vulnerabilities, and men and women are vulnerable differently. The vulnerability was due to the exposure to the flooding, which damaged women's economies, bodies, health, and limited the capacity to adapt to that new environment. In general, the vulnerability of women in the flooding is still influenced by social norms and stereotypes. Women are vulnerable due to the flooding and social rules brought to them.

From the above results, the research found that the MOVE framework on three patterns of vulnerability is acceptable to recognize the difference among women in vulnerability: different exposure levels, women's sensitivities, and limited capacities. The research provided the necessary information for the previous studies in Can Tho City that were not covered by these studies. Specifically, there are differences in the flooding management between men and women in the family and community that Garchagen (2015) has not mentioned in his research in the city. Moreover, the research results go further and more specifically the difference between men and women losses in each family, especially clarifying the three losses of women that Danh (2015) has not mentioned. Also, this research clarified the different economic losses among women based on different livelihood activities that Chinh et al. (2016) missed to focus.

The research results showed the reflection to the theories that other scholars have mentioned about vulnerability, loss, damage, and even capabilities. In everyday life, each person has different constants of vulnerability as well as they have different constants of vulnerability in the different environmental contexts. In this flooding context, the research showed that each woman has a different constant vulnerability, the constant of vulnerability are exposing to different levels of flooding, sensitivity and capacities. This also meant that this constant is different to men.

In the study of flooding particularly and other social disasters in general, the level of exposure needs to be mentioned because it is related to the sensitivity and capacity of each person in order to face and adapt to it. The 
research found that people have different levels of exposures from different types of disasters, which also reflected different vulnerability.

Based on the different exposures of flooding, susceptibilities, and capacities, the results are useful for gender development policies and other development programmes. Specifically, the Law on Gender Equality 2017 in Vietnam has not yet reflected and distinguished this difference clearly in disaster events, this research would contribute for the reference and improvement. Furthermore, the gender development agenda of the investment programs in Vietnam is being planned and drafted, this research provides some information on how to integrate gender development in development projects effectively.

The research found that women are always more vulnerable than men in flooding disasters. It also meant that women are "victim" subject. Women faced the problem because of the social stereotypes (norms), it has not been changing in the gender differences. The solution is that society needs to change the way to look at women, not seeing them as "victim" objects. It is necessary to understand and recognize the differences among women, and between women and men in society in order to recommend more appropriate policies and development programs. However, this research has not explored the potential impacts and the coping strategies among women of this vulnerability in the levels of individual, family, and community. Furthermore, the research has not examined the diverse social group in order to reflect the broader vulnerability.

\section{Acknowledgments}

The author would like to thank the Urban Climate Resilience for Southeast Asia (UCRSEA) Partnership research project (Canada) for financial support in undertaking the research.

\section{References}

Ajibade, I., Gordon, M., \& Rachel, B. (2013). Urban Flooding in Lagos, Nigeria: Patterns of Vulnerability and Resilience among Women. Global Environmental Change, 23(6), 1714-1725. https://doi.org/10.1016/j.gloenvcha.2013.08.009

Anh, T. T., Phong, T. V. G., Ha, N. T. K., \& Cuong, D. Q. (2016). Gender analysis in building climate resilience in Da Nang. Asian Cities Climate Resilience, Working Paper Series 12.

Birkmann, J. (2013). Measuring Vulnerability to Natural Hazards: Towards Disaster Resilient Societies (2nd ed.). United Nations University Press. USA.

Bohle, H. G., Downing, T. E., \& Watts, M. J. (1994). Climate Change and Social Vulnerability: Toward a Sociology and Geography of Food Security. Global Environmental Change, 4(1), 37-48. https://doi.org/10.1016/0959-3780(94)90020-5

Chambers, R. (2006). Editorial Introduction: Vulnerability, Coping and Policy. IDSBulletin, 20(2), 1-7. https://doi.org/10.1111/j.1759-5436.1989.mp20002001.x

Chanthy, S., \& Samchan, H. (2014). Flood Impacts on Women: Exploring the Possibility of Gender Sensitive DRR Planning. Cambodia: Action Aid Report.

Chinh et al. (2016). The 2011 flood event in the Mekong Delta: Preparedness, response, damage and recovery of private households and small businesses. Disaster, 40(4), 753-778, USA. https://doi.org/10.1111/disa.12171

CPC. (2017). The Investment Infrastructure Project in Can Tho City 2017 from ODA Funding. Can Tho City People Committee.

Dahlberg, R., Albris, K., \& Jebens, M. (2017). The Baltic Storm Surge in November 1872: Urban Processes, Gendered Vulnerability and Scientific Transformation. In D. Simonton, \& H. Salmi (Eds.), Catastrophe, Gender and Urban Experience, 1648-1920. New York and Oxon: Routledge. https://doi.org/10.4324/9781315522814-ch-10

Danh, V. T. (2015). Household Economic Losses of Urban Flooding: Case Study of Can Tho City, Vietnam. Asian Cities Climate Resilience, Working Paper Series 12.

Ehlert, J. (2011). Living with Flood-Local knowledge in the Mekong Delta, Vietnam. Berlin: Lit Verlag.

Ellis, C. (2004). The Ethnographic I: A Methodological Novel about Ethnographic Alternatives. New York: Alta Mira Press.

Enarson, E. (2011). What Women Do: Gendered Labor in the Red River Valley Flood. Environmental Hazards, 3(1), 1-18. https://doi.org/10.3763/ehaz.2001.0301

Garschagen, M. (2015). Risky Change? Vietnam's Urban Flood Risk Governance Between Climate Dynamics 
and Transformation. Pacific Affairs, 88(3), 599-621. https://doi.org/10.5509/2015883599

Huong, H. T. L., \& Pathirana, A. (2013). Urbanisation and Climate Change Impacts on Future Urban Flooding in Can Tho City, Vietnam. Earth Syst. Sci., 17, 379-394. https://doi.org/10.5194/hess-17-379-2013

Lubrano, S. S. (2013). Vulnerability as a Key to Feminism. Online publication: Manifest Magazine.

Matainbanadzo, S. (2012). Embodying Vulnerability: A Feminist Theory of the Person. Duke Journal of Gender Law \& Policy, 20.

MONRE. (2012). Climate Change, Sea Level Rise Scenarios of Vietnam. Vietnam Government Information Gate.

Mustafa, D. (2005). The Production of an Urban Hazardscape in Pakistan: Modernity, Vulnerability, and the Range of Choice. Annals of the Association of American Geographers, 95(3), 566-586. https://doi.org/10.1111/j.1467-8306.2005.00475.x

Trung, N. V. D. (2012). Urbanisation Studies and its Effects to Social and Economic Development in Can Tho City. University of Training and Education, Ho Chi Minh City (Full PhD thesis).

Vietnam Gender Inequality Law. (2017). Government of Vietnam.

\section{Copyrights}

Copyright for this article is retained by the author(s), with first publication rights granted to the journal.

This is an open-access article distributed under the terms and conditions of the Creative Commons Attribution license (http://creativecommons.org/licenses/by/4.0/). 